\title{
ON THE SEASONAL ABUNDANCE OF YOUNG FISH. V. THE YEAR 1937
}

\author{
By F. S. Russell, B.A., F.R.S.
}

Naturalist at the Plymouth Laboratory

\section{(Text-figs. I-4)}

The present report continues the observations on the seasonal abundance of the pelagic young of teleostean fish in the plankton off Plymouth (Russell, I937) and gives the results for the year 1937. These results are published in the same form as in previous reports. The dates on which collections were made with the 2-metre stramin ringtrawl are given in Table I and the monthly average catches of the young fish per half-hour haul in Table II. In Fig. I is given the curve for the average catches for each fortnight of all young fish, excluding clupeids, and superimposed upon this the corresponding curve for the average catches over the period 1930-I934 inclusive.

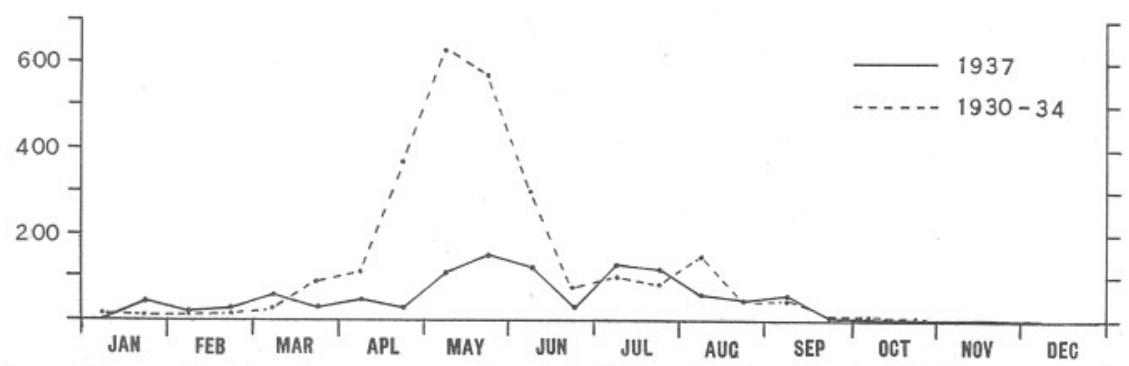

Fig. I. Curves showing the average catches in half-hour oblique hauls with the 2-metre ringtrawl for each fortnight for all young fish, excluding clupeids, in $1937(-)$ and the same averaged over the period r930-I934 inclusive (-----).

The results for 1937 are almost a repetition of those for I936. Once more there was an almost complete absence of the usual peak of the young of spring spawners and there were again slightly higher numbers of the young of summer spawners. The sum of the monthly average catches of those post-larvae which show maximal abundance in the months June to October inclusive, excluding clupeids, was 174 in 1937 as against II5 in 1936. These numbers were mainly made up by Arnoglossus sp., C.trachurus, C.rupestris, S. scombrus, and $B$. gattorugine. There thus appears to be a gradual swing over to better conditions for summer spawners in contrast to spring spawners the significance of which is not yet apparent.

The sums of the average monthly catches of the more important species for the year 1937 divided by the corresponding average sums for the period 
I930-I934 inclusive are given below. In the second column are the figures for the best year divided by the worst year from I930 to 1937 inclusive.

$\begin{array}{lc}\text { G. merlangus } & \text { Av. } 1930-34 \\ \text { G. minutus } & 0.19 \\ \text { Onos spp. } & 0.15 \\ \text { Arnoglossus spp. } & 0.40 \\ \text { S. norvegicus } & \mathrm{I} \cdot 09 \\ \text { P. limanda } & 0.14 \\ \text { P. microcephalus } & 0.35 \\ \text { S. variegata } & 0.04 \\ \text { Callionymus spp. } & 0.24 \\ \text { S. scombrus } & 0.28 \\ \text { Gobiid spp. } & \mathrm{I} \cdot 68 \\ & 0.02\end{array}$

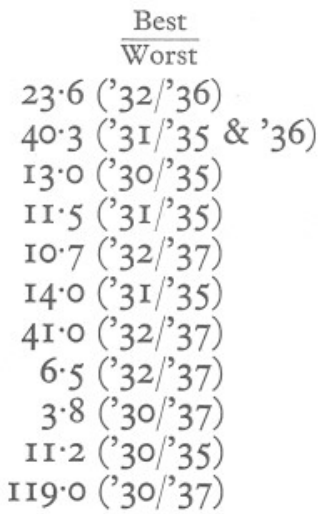

The year 1937 has been the worst during the period I930-I937 for S. norvegicus, P. microcephalus, S. variegata, Callionymus spp., and Gobiid spp. Except for Callionymus, however, the numbers of these species are becoming so low, even in some species reaching unity, that undue significance should no longer be placed on high values for the calculated figures for best divided by worst years.

The numbers of Callionymus have fallen from an average of 548 for the period 1930-I934 to only I55 in I937. This decrease is very noticeable in the catches because young Callionymus usually bulk so largely that they are a characteristic feature of Plymouth plankton. But in spite of their decrease in actual numbers their proportionate representation is still 0.28 of the catches of all young fish, excluding clupeids, as compared with 0.38 for the period 1930-1934. The fact that this, the most abundant species, still forms approximately the same proportion of the young fish population indicates that the decrease in the numbers of young fish during the last few years has been due to some factor adverse to all species of fish indiscriminately. Indeed, if this decrease had been due to an overfishing of the reproducing stock it might have been expected that there would have been a corresponding increase in the proportionate numbers of the young of those species of fish which are not taken by the trawl. The gobies for instance might have benefited, whereas actually their numbers have dwindled to insignificance. This adds further support to the argument that it is the decrease in the amount of available phosphorus in the water which is the root cause of the poor survival of young fish.

In 1937 both Arnoglossus and Scomber were slightly above the average for 1930-1934, but the latter came nowhere near the high figure of 344 recorded for 1926 . A noteworthy feature in 1937 was the unusual abundance of the young of Serranus cabrilla of which a catch of 24 was made on September I. 
The results for all species of young fish for the last eight years are summarized in Fig. 2. This figure shows the yearly averages for total young fish (excluding clupeids), for the young of summer spawners, and for total young fish less the young of summer spawners. It shows clearly how the drop in numbers after I930 occurred first among the young of summer spawners, and that the decrease in the numbers of other species, mainly spring spawners, started later, reaching a very low level in 1935 at which it has remained while the summer spawned fish have slightly improved.

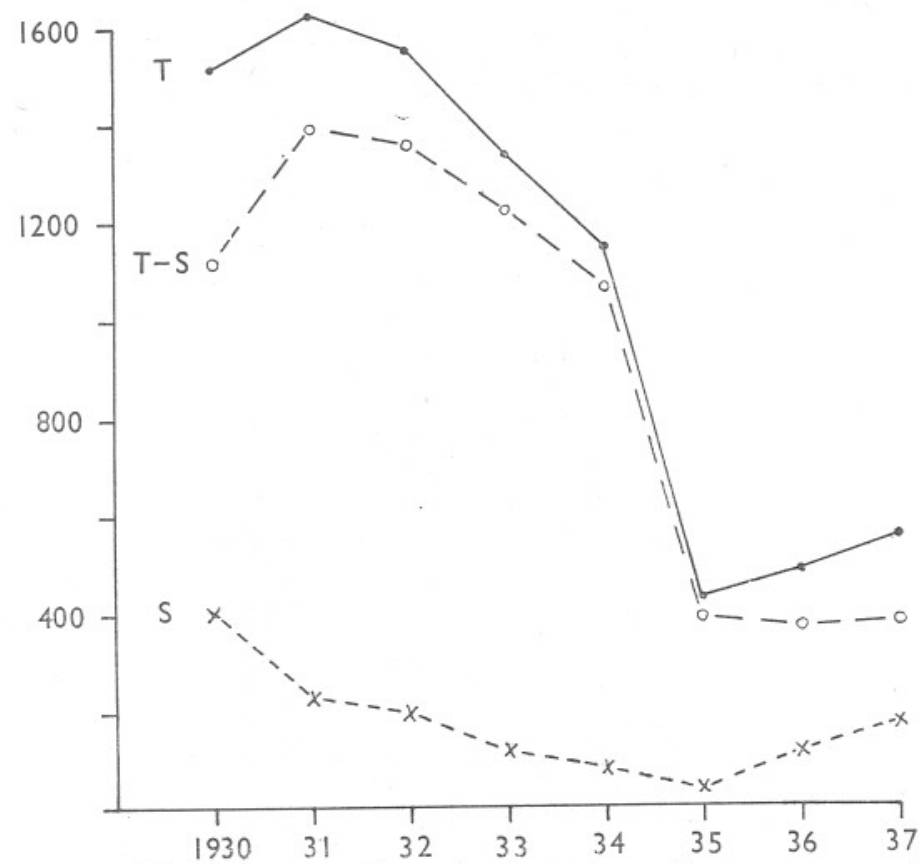

Fig. 2. The sums of the average monthly catches for each year from 1930 to 1937 in half-hour oblique hauls with the 2-metre ringtrawl for: $T$, total young fish (excluding clupeids); $S$, the young of summer spawners; and $T-S$, total young fish less the young of summer spawners.

In previous reports it was suggested that we must await a fresh inflow of water from the south of Ireland into the Channel to replenish the supply of phosphorus before there will be a return to conditions for good survival of young fish. It seemed most likely that this replenishment will come from the "elegans" water. So far there are no indications of a return to the conditions of I930 when "elegans" water predominated off Plymouth. Figs. 3 and 4 give data on the occurrence of plankton indicators in the catches off Plymouth in I937 in continuation of those given in the last report (I937, Figs. 2 and 3). The year I937 was very similar to I936. The numbers of both species of Sagitta were extremely low until August, when S. setosa became abundant, and 

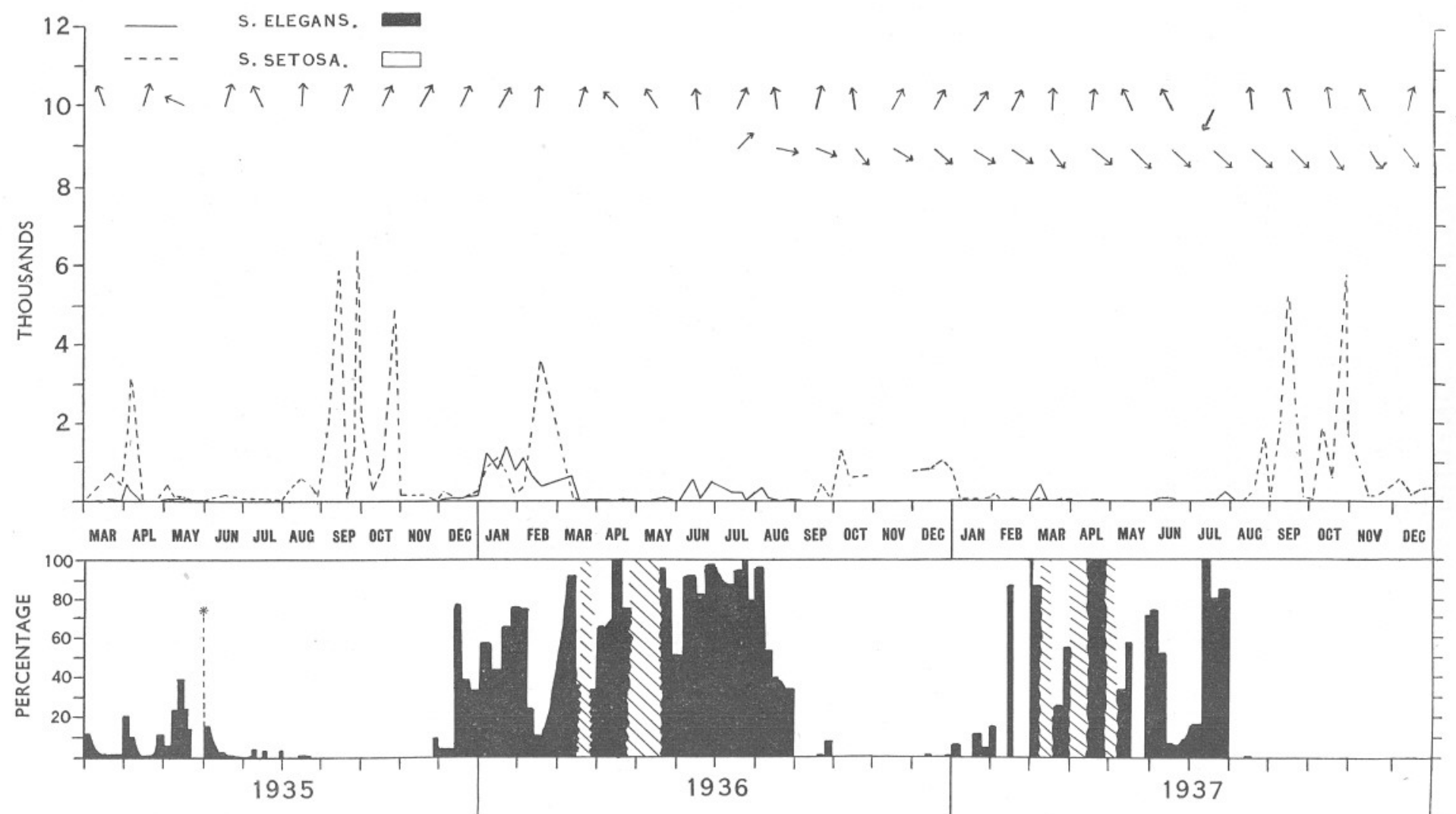

Fig. 3. Above, curves showing the actual abundance of $S$. elegans (-) and $S$. setosa (-----) in half-hour oblique hauls with the 2-metre ringtrawl during the period March I935 to-December 1937.

Below, the percentage composition of the Sagitta populations during the same period: S. elegans, black; S. setosa, white; no Sagitta, hatched.

At the top of the diagram the arrows indicate the mean directions (true) of the flow of water past the Varne Lightship (above) and the Royal Sovereign Lightship (below) from data kindly supplied by Dr J. N. Carruthers. (Continued from Russell, I937, p. 68I, Fig. 2.) 
what S. elegans there were were much fewer than in 1936 . The siphonophore Muggiaea atlantica was again abundant in the later summer and autumn. As in 1936 the low numbers of S. elegans in the first half of the year were accompanied by the appearance of unusual species. On February 24 another specimen of the scyphomedusa Discomedusa lobata was caught and several Pelagia

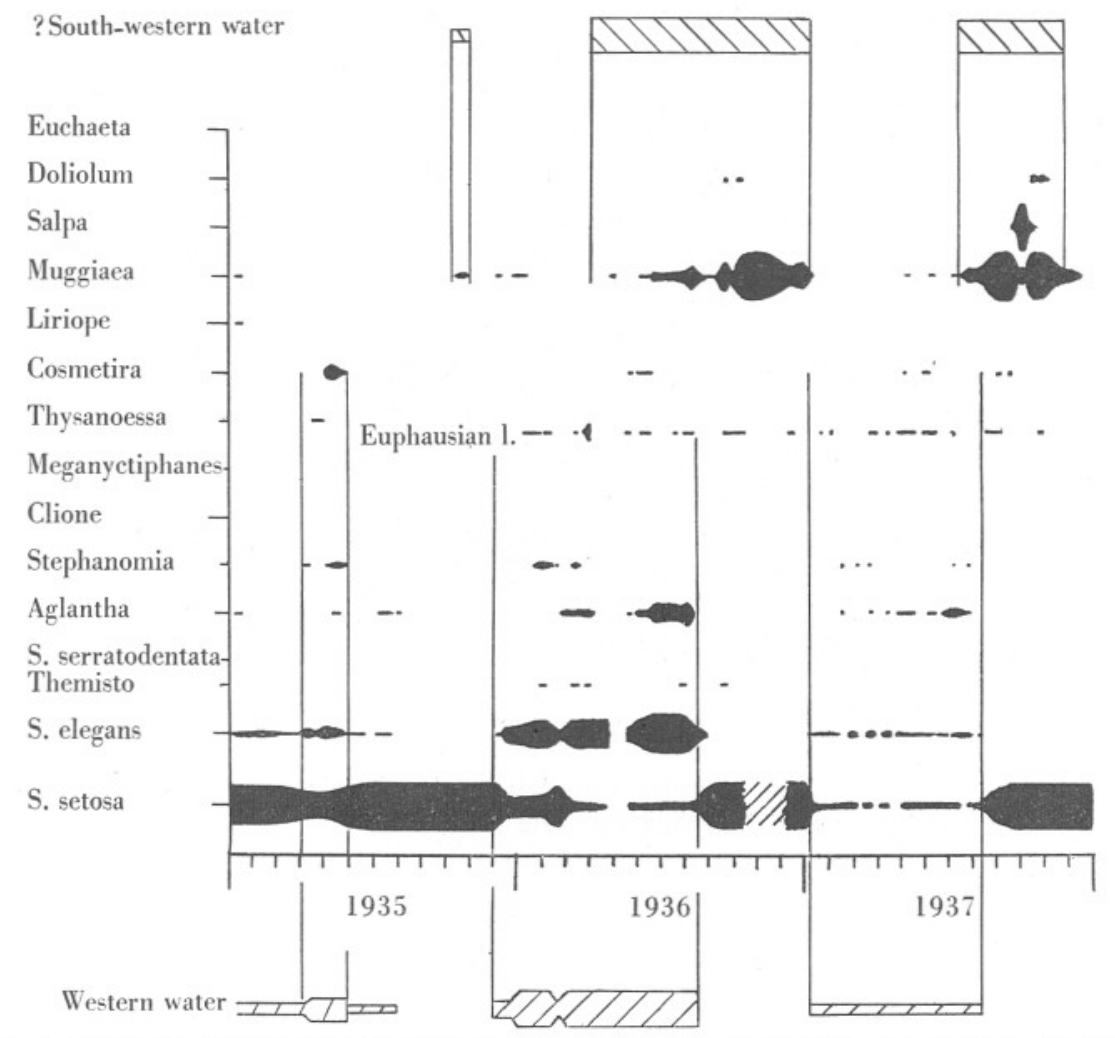

Fig. 4. Diagram showing the occurrence of the various plankton indicators in the collections off Plymouth during the years I935, I936 and I937. (Continued from Russell, I937, p. 682 , Fig. 3.)

The Muggiaea species were M. kochi up to January 1937, and thereafter M. atlantica, the salps were $S$. fusiformis, and the doliolids $D$. nationalis.

were present in April. These two species were recorded in 1936 for the first time off Plymouth. In addition, in 1937 one specimen of the copepod Rhincalanus nasutus was taken on February 9; this is the first time the species has been recorded off Plymouth. It is perhaps also of interest that on February 23 the Salpa landed a catch with many small hake.

On September 20 Salpa fusiformis appeared in the catches and had disappeared by October 19. Although the salps were not found off Plymouth on 
September I3 they were present on the next day off Looe. This is the first appearance of salps off Plymouth since 1932.

As in 1936 also, pilchard eggs were a distinct feature in the plankton in 1937. They were present continuously from April to December, the approximate numbers on the different dates being as follows: April I4 (280), 26 (2320); May 3 (2360), Io (37, 300), I9 (I000), 24 (2800), 3I (4200); June 6 (480), I4 (30,000), I8 (I9,220); July 5 (I4,960), I3 (7920), I9 (few), 26 (few); August 4 (I220), II (880); September I (I000), 7 (few), I3 (few), 20 (few), 27 (90); October 4 (I00), II (320), 26 (few); November I (2420), 8 (300), I5 (670), I9 (20); December 6 (4), I3 (I), 3I (II).

The continuous appearance of such large numbers of pilchard eggs under conditions when the numbers of both $S$. elegans and $S$. setosa are conspicuously low deserves special mention, as it appears possible that we have here a body of water distinct from either of those characterized by the presence of S. elegans or S. setosa. If this be so, or whatever be the origin of this water, it is proposed that it should for the time being be called "pilchard" water, since it is evident that it is well worth watching in the future for the conditions that favour this great production of pilchard eggs off Plymouth.

In spite of the large number of eggs there are no indications in the ringtrawl catches that the young were abnormally abundant. The possibility that the low numbers of $S$. setosa may also be owing to their poor survival must not be lost sight of, but we do not know how abundant they were in the eastern half of the Channel.

\section{REFERENCE}

Russell, F. S., 1937. The seasonal abundance of the pelagic young of teleostean fishes in the Plymouth area. Part IV. The year 1936, with notes on the conditions as shown by the occurrence of plankton indicators. Fourn. Mar. Biol. Assoc., Vol. xxI, pp. 679-86. 


\section{Table I. Dates on Which Collections Were Made, I937}

All 2 miles east of Eddystone unless otherwise stated

Jan. Feb. March April May June July Aug. Sept. Oct. Nov. Dec.

\begin{tabular}{|c|c|c|c|c|c|c|c|c|c|c|c|}
\hline $6^{\star}$ & 2 & I & 6 & 3 & 6 & 5 & 4 & I & 4 & I & 6 \\
\hline $\mathrm{I} 2^{\star}$ & 9 & 8 & I 4 & IO & I 4 & I3 & II & 7 & II & 8 & $\mathrm{I}_{3}$ \\
\hline 20 & I6 & I9‡ & $19 \$$ & I8 & I8 & 19 & I8 & I3 & I9 & I5 & 20 \\
\hline \multirow[t]{2}{*}{$27 \dagger$} & 24 & 23 & 26 & 24 & & 26 & 25 & 20 & 26 & I9 & $3 I$ \\
\hline & & 30 & & $3 I$ & & & & 27 & & & \\
\hline
\end{tabular}

\footnotetext{
* $\mathrm{L}_{4}-\mathrm{L} 5$.

$\S$ Off Revelstoke, 25 fathoms.

+ Bolt E $\times$ S: Stoke Pt. N.

II 4-5 miles south of Breakwater.

$\ddagger \mathrm{L}_{3}-\mathrm{L}_{4}$.

9. 3 miles west of Rame.
} 


\section{Table II. Average Monthly Catches of Post-larvae Per Half-hour}

Oblique hauls with 2-metre Ringtrawl, I937

Total Young Fish

Ditto, less Clupeids

All Clupeid spp.

Clupea harengus

Gadus pollachius

Gadus merlangus

Gadus minutus

Gadus luscus

Gadus callarius

Onos spp.

Molva molva

Merluccius merluccius

Raniceps raninus

Capros aper

Zeus faber

Arnoglossus spp.

Rhombus spp.

Scophthalmus norvegicus

Zeugopterus punctatus

Zeugopterus unimaculatus

Pleuronectes limanda

Pleuronectes flesus

Pleuronectes microcephalus

Solea vulgaris

Solea variegata

Solea lascaris

Solea lutea

Serranus cabrilla

Caranx trachurus

Mullus surmuletus

Morone labrax

Ammodytes sp.

Ammodytes lanceolatus

Cepola rubescens

Callionymus spp.

Labrus bergylta

Labrus mixtus

Ctenolabrus rupestris

Crenilabrus melops

Centrolabrus exoletus

Trachinus vipera

Scomber scombrus

Gobius spp.

Lebetus scorpioides

Blennius ocellaris

Blennius pholis

Blennius gattorugine

Chirolophis galerita

Agonus cataphractus

Trigla spp.

Cottus sp.

Liparis montagui

Lepadogaster bimaculatus

Lophius piscatorius
Jan. Feb. Mar. Apr. May June July Aug. Sept. Oct. Nov. Dec. $\Sigma$

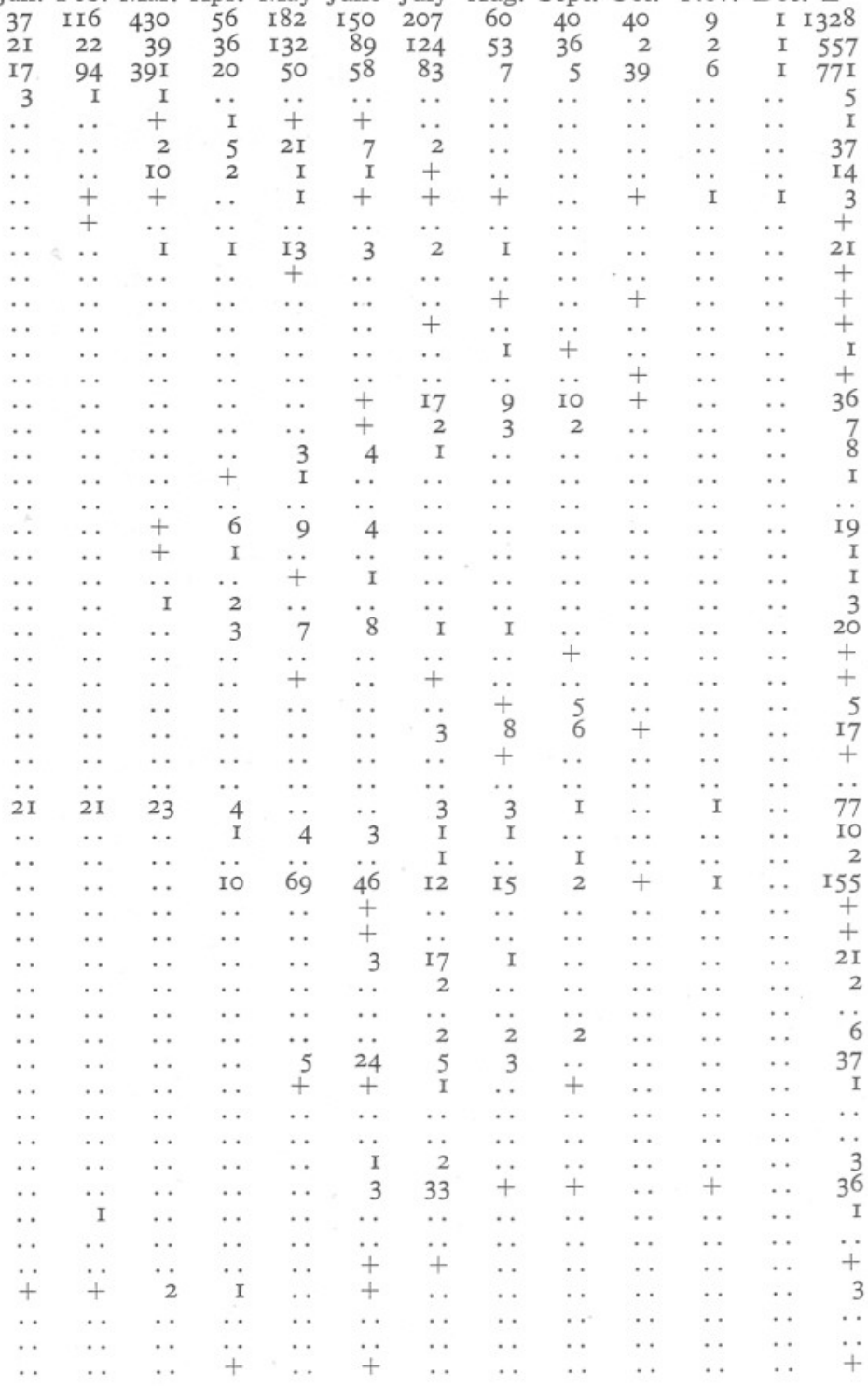

